\title{
Immune response evaluation in Balb/c mice after crude extract of Anisakis typica sensitization
}

\author{
Linda Haryadi ${ }^{1,2}$, Eddy Suprayitno ${ }^{3}$, Aulanni'am Aulanni'am ${ }^{4}$ and Anik Martinah Hariati ${ }^{5}$
}

1. Doctoral Program, Faculty of Fisheries and Marine Sciences, Brawijaya University, Jalan Veteran, Malang 65145, East Java, Indonesia; 2. Fish Quarantine and Inspection Agency of Kupang, Jalan Ade Irma No 6 Walikota, Kupang 85228,

East Nusa Tenggara, Indonesia; 3. Department of Food Processing Technology, Faculty of Fisheries and Marine Sciences, Brawijaya University, Jalan Veteran, Malang 65145, East Java, Indonesia; 4. Department of Biochemistry, Faculty of Sciences, Brawijaya University, Jalan Veteran, Malang 65145, East Java, Indonesia; 5. Department of Aquaculture, Faculty of Fisheries and Marine Sciences, Brawijaya University, Jalan Veteran, Malang 65145, East Java, Indonesia.

Corresponding author: Anik Martinah Hariati, e-mail: a_hariati@ub.ac.id

Co-authors: LH: caluna.maia@gmail.com,ES: eddysuprayitno@ub.ac.id, AA: aulani@ub.ac.id

Received: 12-06-2019, Accepted: 27-08-2019, Published online: 04-10-2019

doi: 10.14202/vetworld.2019.1529-1534 How to cite this article: Haryadi L, Suprayitno E, Aulanni'am A, Hariati AM (2019) Immune response evaluation in Balb/c mice after crude extract of Anisakis typica sensitization, Veterinary World, 12(10): 1529-1534.

\begin{abstract}
Background and Aim: Anisakis is a global challenge for a fish product which may lead to a decrease in economic value and consumers' preference. Skipjack (Katsuwonus pelamis) in Kupang, Nusa Tenggara Timur, Indonesia, have important economic value for local fisheries. Anisakis typica is one of the Anisakis species which potent to induce an allergic reaction. However, the study about $A$. typica involved in the dendritic cells (DCs), T helper $1\left(\mathrm{Th}_{1}\right)$, $\mathrm{T}$ helper $2\left(\mathrm{Th}_{2}\right)$, and regulatory $\mathrm{T}$ cells (Tregs) is still limited. This study aimed to analyze the dynamic changed of the immune system including DCs, CD4 ${ }^{+}$ T cells, and Tregs after 1 week of $A$. typica sensitization.

Materials and Methods: Twenty-four male Balb/C mice were randomly divided into four groups ( $\mathrm{n}=6)$, mice treated with crude $A$. typica extract (CAE) 50, 75, and $100 \mathrm{mg} / \mathrm{kg} \mathrm{BW}$, respectively. CAE was given orally per day for a week. At the end of the experiment, the animals were sacrificed and the spleen was collected. DCs were labeled as CD11 $\mathrm{c}^{+}$interleukin- $6^{+}$ $\left(\mathrm{IL}-6^{+}\right)$; $\mathrm{CD}^{+} \mathrm{T}$ cells were distinguished as Th $\left(\mathrm{CD} 4^{+}\right.$interferon- $\left.\gamma^{+}\left[\mathrm{IFN}-\gamma^{+}\right]\right)$and $\mathrm{Th}\left(\mathrm{CD} 4^{+} \mathrm{IL}-4^{+}\right.$and $\left.\mathrm{CD} 4^{+} \mathrm{IL}-5^{+}\right)$; Tregs were labeled as $\mathrm{CD} 4{ }^{+} \mathrm{CD} 25^{+} \mathrm{CD} 62 \mathrm{~L}^{+}$. The expression of each cell was determined by flow cytometry.
\end{abstract}

Results: Our result described that CAE elicits CD $11 \mathrm{c}^{+} \mathrm{IL}_{-} 6^{+}, \mathrm{CD} 4^{+} \mathrm{IFN}-\gamma^{+}, \mathrm{CD} 4^{+} \mathrm{IL}_{-} 4^{+}$, and $\mathrm{CD} 4^{+} \mathrm{IL}_{-} 5^{+}$and reduces $\mathrm{CD} 4{ }^{+} \mathrm{CD} 25^{+} \mathrm{CD} 62 \mathrm{~L}^{+}$significantly $(\mathrm{p}<0.05)$ in dose-dependent manner in mice after A. typica infection.

Conclusion: The $\mathrm{Th}_{1} / \mathrm{Th}_{2}$ ratio after $A$. typica crude extract treatment exhibits a mixed pattern rather than the classical model allergy to food antigens. Our study is expected as a basic understanding of the changes in immune response after $A$. typica infection.

Keywords: allergy, dendritic cells, inflammation, nematode, regulatory T cells.

\section{Introduction}

Food safety and food security due to food-borne infections are gaining interest in the past decade $[1,2]$. Anisakiasis, the zoonotic disease caused by nematode larvae of the genus Anisakis is considered as one of the most important biohazards in the fish products [3]. The previous study reported that Anisakis spp. were found in commercially fish, particularly anchovies (Engraulis encrasicolus), sardines (Sardina pilchar$d u s$ ), European hake (Merluccius merluccius), whiting (Merlangius merlangus), chub mackerel (Scomber japonicus), and Atlantic bluefin tuna (Thunnus thynnus) [4].

Anisakis spp. have a complex life cycle and reach maturation in the third stage (L3). Marine mammals are

Copyright: Haryadi, et al. Open Access. This article is distributed under the terms of the Creative Commons Attribution 4.0 International License (http://creativecommons.org/licenses/ by/4.0/), which permits unrestricted use, distribution, and reproduction in any medium, provided you give appropriate credit to the original author(s) and the source, provide a link to the Creative Commons license, and indicate if changes were made. The Creative Commons Public Domain Dedication waiver (http:// creativecommons.org/publicdomain/zero/1.0/) applies to the data made available in this article, unless otherwise stated. a final host to complete its life cycle [5]. A human can accidentally be infected by Anisakis after consumed the raw or half-cooked fish meats, which is strongly associated with acute gastrointestinal (GI) symptoms [6] and allergen reaction [7]. Both live and death larva of Anisakis could induce the allergic reaction due to its thermal- and pepsin-resistant properties [5,8]. Interestingly, the simple prepared crude extract of Anisakis is enough to induce the allergic reaction [9].

The allergic reaction due to Anisakis has been reported to elicit the host immune response which is characterized by $\mathrm{T}$ helper $2\left(\mathrm{Th}_{2}\right)$ response predominantly by secreting cytokines such as interleukin-4 (IL-4) and IL-5 [10]. Furthermore, T helper $1\left(\mathrm{Th}_{1}\right)$ maturation by dendritic cells (DCs) was suppressed by regulatory $\mathrm{T}$ cells [11] which assist $\mathrm{Th}_{2}$ polarization during helminth infection. This regulatory network results in the decrease of interferon- $\gamma($ IFN- $\gamma$ ), the cytokine which secreted by $\mathrm{Th}_{1}$ [12]. In contrast, the previous study reported that Anisakis allergy exhibits a mixed $\mathrm{Th}_{1} / \mathrm{Th}_{2}$ pattern [13]. Meanwhile, prolonged nematode infection may lead to chronic infection predominantly by $\mathrm{Th}_{1}[14]$.

Nowadays, there are nine Anisakis species which have been confirmed [15]. Among them, Anisakis 
simplex sensu stricto (s.s) and Anisakis pegreffii are the best known caused the allergic reaction and other health problems [16]. However, as far as our knowledge, there is little information about allergen reaction which involved immune cells such as DCs, $\mathrm{Th}_{1}, \mathrm{Th}_{2}$, and regulatory T cells (Tregs) caused by Anisakis typica. A. typica have been found parasitizes Delphinidae, Phocoenidae, and Pontoporidae in Atlantic and Indian Oceans and in the Eastern Mediterranean Sea. Surprisingly, A. typica also found in Australian and Indonesia [17]. This finding increases the potential risk for anisakiasis frequency in Southeast Asia, mainly in Indonesia.

This study aimed to evaluate the immune response underlying host after A. typica infection. The present study is expected as a basic understanding of A. typica accidental infection due to marine products and, subsequently, develops the intervention strategies.

\section{Materials and Methods}

\section{Ethical approval}

This study was approved by the Ethical Committee of Brawijaya University (approval number 938-KEP-UB).

\section{Animals}

Male $\mathrm{Balb} / \mathrm{C}$ mice aged 5 weeks were supplied from the Integrated Research and Testing LaboratoryUnit IV, Gadjah Mada University. Mice were housed in plastic cages for a period of acclimatization. Mice were given food and water ad libitum and maintained at room temperature with a $12 \mathrm{~h}$ light/dark cycle.

\section{Crude A. typica preparation}

Skipjack (Katsuwonus pelamis) were purchased from the traditional market in Kupang, Nusa Tenggara Timur, Indonesia. A. typica was manually harvested from the abdominal cavity of skipjack which naturally parasitized by A. typica. A. typica was identified by polymerase chain reaction according to Soewarlan et al. [18] using NC5 (forward; 5'-GTAGGTGAACCTGCGGAAGATCATT-3') and NC2 (reverse: 5'-TTAGTTTCTTTTCCTCCGCT-3') primer (data not shown). A. typica washed with distilled water then stored at $4^{\circ} \mathrm{C}$. The crude extract of A. typica was made by crushed $A$. typica using porcelain mortar and pestle at $4{ }^{\circ} \mathrm{C}$. The protein content of milled A. typica then measured using nanodrop spectrophotometer (ND1000). The protein content then considered as a standard to determine the dosage given to animals.

\section{Experimental design}

Twenty-four male Balb/C mice weight $25 \mathrm{~g}$ were randomly and equally divided into four groups $(\mathrm{n}=6)$ : Normal (unsensitized mice) and mice treated with crude Anisakis extract (CAE) 50, 75, and $100 \mathrm{mg} / \mathrm{kg} \mathrm{BW}$, respectively. Mice were intragastrically challenged per day for 7 days consecutively with CAE, except the normal group. At the $8^{\text {th }}$ day, mice were anesthetized through intraperitoneal injection the combination of ketamine and xylazine (90 $\mathrm{mg} / \mathrm{kg}$ and $10 \mathrm{mg} / \mathrm{kg}$, respectively) [19] followed by euthanized by cervical dislocation. The spleen was collected and washed 3 times in sterile phosphate-buffered saline (PBS) then crushed into single-cell suspensions. Single-cell suspensions then added with PBS until reached $10 \mathrm{~mL}$ and centrifuged at $2500 \mathrm{rpm}$ for $5 \mathrm{~min}$ at $10^{\circ} \mathrm{C}$. The supernatant then discarded and the pellet was homogenized with $1 \mathrm{~mL}$ PBS [20]. Homogenates then divided into several $1.5 \mathrm{~mL}$ tubes according to the staining used then centrifuged at $2500 \mathrm{rpm}$ for 5 min at $10^{\circ} \mathrm{C}$.

\section{Cell staining and flow cytometry analysis}

The supernatant then discarded and the pellet stained according to: (1) To determine Th cells, cells surface was stained with fluorescein isothiocyanate (FITC) anti-mouse CD4 (BioLegend, clone: GK1.5), (2) regulatory $\mathrm{T}$ cells were identified by a combination of cell surface antibodies of FITC anti-mouse CD4 (BioLegend, clone: GK1.5), phycoerythrin (PE) anti-mouse CD25 (BioLegend, clone: 3C7), and PE-Cyanine5 (PE-Cy5) anti-mouse CD62L (BioLegend, clone: MEL-14), and (3) DCs were identified by cell surface antibodies FITC antimouse CD11c (BioLegend, clone: N418). Briefly, $50 \mu \mathrm{L}$ of Cytofix/Cytoperm Buffer (BioLegend, cat no: 420801) was resuspended in pellet for $20 \mathrm{~min}$ in dark condition at $4^{\circ} \mathrm{C}$. Then, homogenates were added with $300 \mu \mathrm{L}$ wash-perm (BioLegend, cat. no.: 421002 ) and centrifuged at $2500 \mathrm{rpm}$ at $4^{\circ} \mathrm{C}$ for $5 \mathrm{~min}$. Supernatant was discarded, and the pellet was stained with intracellular staining $(50 \mu \mathrm{L})$ of PE anti-mouse IL-6 (BioLegend, clone: MP5-20F3) which combined with CD11c. Pellet which previously stained with anti mouse-CD4 were stained with PE-Cy7 anti-mouse IL-4 (BioLegend, clone: 11B11) and PE-anti-mouse IL-5 (BioLegend, clone: TRFK5) to identified $\mathrm{T}_{h} 2$ Besides, pellet which previously stained with anti mouse-CD4 were stained with PE anti-mouse IFN- $\gamma$ (BioLegend, clone: XMG1.2) to identified $T_{h} 1$. Data were obtained using FACSCalibur ${ }^{\text {TM }}$ (BD Biosciences, San Jose, CA, USA). A total of 10,000 cell events were collected for each sample. The cell suspensions for each sample were collected immediately with low or medium flow rate. The single-cell populations were gated according to the staining used for further analysis. Data analysis was conducted using software BD CellQuest Pro ${ }^{\mathrm{TM}}$ (BD Biosciences, San Jose, CA, USA).

\section{Statistical analysis}

Statistical analyses were performed using Microsoft Excel 2016. All data were expressed as mean \pm standard deviation. $\mathrm{p}<0.05$ was determined using one-way ANOVA followed by Duncan's multiple range test. 


\section{Results}

Anisakis treatment elicits DCs activation and decline regulatory $\mathbf{T}$ cell

Dose-dependent increase DCs in mice treated with $A$. typica crude extract (Figure-1a). The degree of $\mathrm{CD}_{11 \mathrm{c}^{+}}$IL- $6^{+}$was increasing significantly $(p<0.05)$ in treated mice compared with normal mice (Figure-1c). In contrast, regulatory $\mathrm{T}$ cells expression $\left(\mathrm{CD} 4{ }^{+} \mathrm{CD} 25^{+} \mathrm{CD} 62 \mathrm{~L}^{+}\right)$was decline significantly $(p<0.05)$ in treated mice compared with normal mice (Figure-1b). The increase of CD $11 \mathrm{c}^{+} \mathrm{IL}-6^{+}$and the decrease of $\mathrm{CD}_{4}{ }^{+} \mathrm{CD} 25^{+} \mathrm{CD} 62 \mathrm{~L}^{+}$showed a dose-dependent manner after $A$. typica crude extract treatment (Figure-1c).
Anisakis treatment enhance $\mathrm{Th}_{1} / \mathrm{Th}_{2}$ ratio in sensitized mice

To determine how the immune response shifted after $A$. typica crude extract treatment, $\mathrm{Th}_{1^{-}}$and $\mathrm{Th}_{2}$-related cytokine productions were analyzed in the spleen (Figure-2a). Our result suggests that $\mathrm{Th}_{2}$ $\left(\mathrm{CD}^{+} \mathrm{IL}^{-} 4^{+}\right.$and $\left.\mathrm{CD} 4^{+} \mathrm{IL}_{-} 5^{+}\right)$was increased significantly $(\mathrm{p}<0.05)$ after $A$. typica crude extract treatment. In addition, $\mathrm{CD}^{+} \mathrm{IFN}_{-} \boldsymbol{\gamma}^{+}\left(\mathrm{Th}_{1}\right)$ also increases significantly $(\mathrm{p}<0.05)$ after $A$. typica crude extract treatment. Interestingly, $\mathrm{CD} 4^{+} \mathrm{IL}-4^{+}$and $\mathrm{CD} 4^{+} \mathrm{IL}-5^{+}$expression were higher in a low dose of A. typica crude extract (Figure-2b). Surprisingly, our present study resulting in a higher expression of $\mathrm{CD}^{+} \mathrm{IFN}-\gamma^{+}$compared to $\mathrm{CD} 4^{+} \mathrm{IL}-4^{+}$and $\mathrm{CD} 4^{+} \mathrm{IL}-5^{+}$expression.

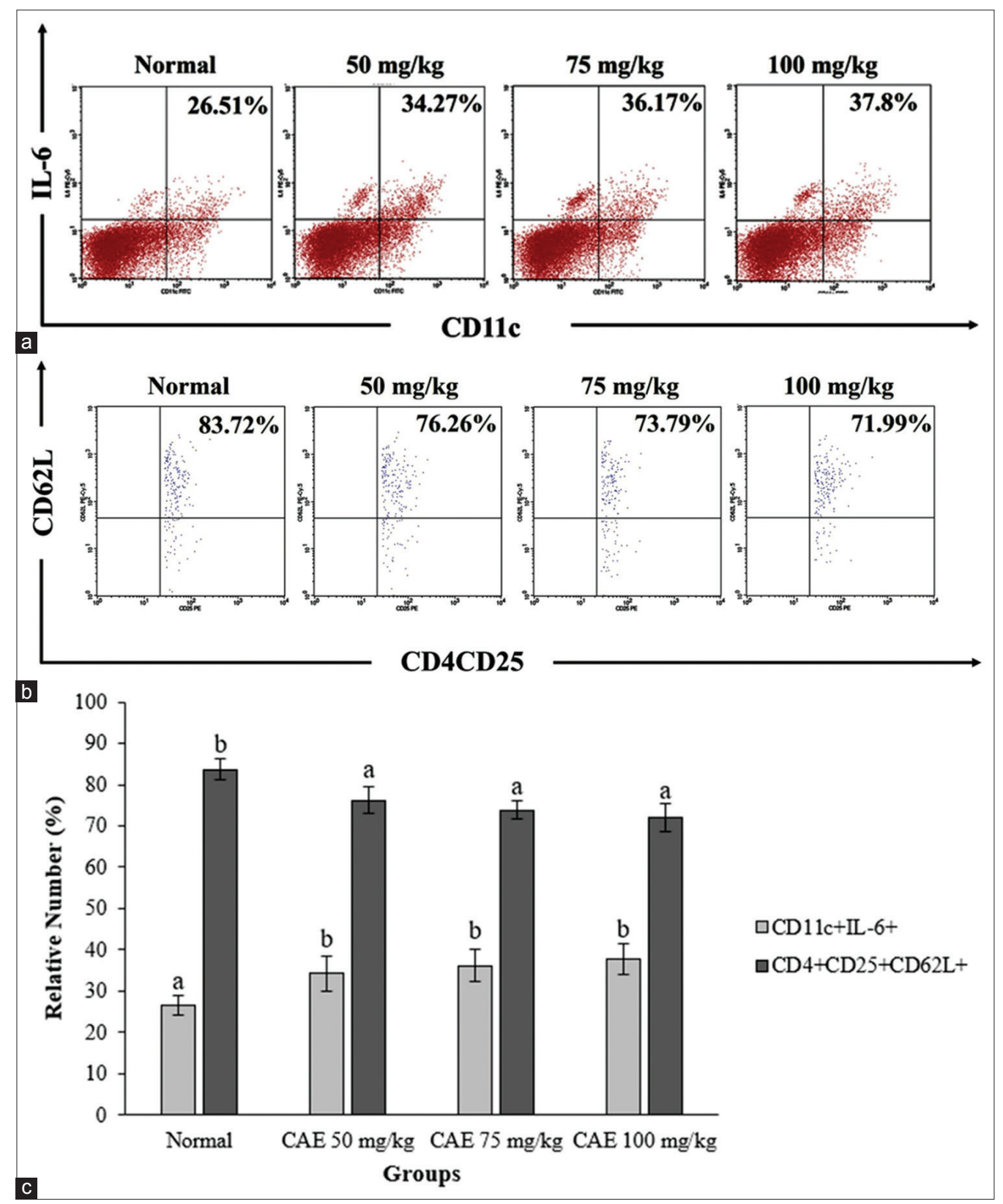

Figure-1: Flow cytometry analysis exhibited dendritic cells and regulatory T cells. (a) CD $11 \mathrm{C}^{+}$interleukin- $6^{+}\left(\right.$IL- $6^{+}$) expressions on splenocytes, (b) CD $4{ }^{+} \mathrm{CD} 25^{+} \mathrm{CD} 62 \mathrm{~L}^{+}$expressions on splenocytes, and (c) $\mathrm{CD} 11 \mathrm{C}^{+} \mathrm{IL}-6^{+}$and $\mathrm{CD} 44^{+} \mathrm{CD} 25^{+} \mathrm{CD} 62 \mathrm{~L}^{+}$ expressions were represented as mean \pm standard deviation ( $n=6$ for each group). The different letter on the chart was considered significantly different for each group $(p<0.05)$ and vice versa based on Duncan's multiple range test. CAE $=C r u d e$ Anisakis extract. 


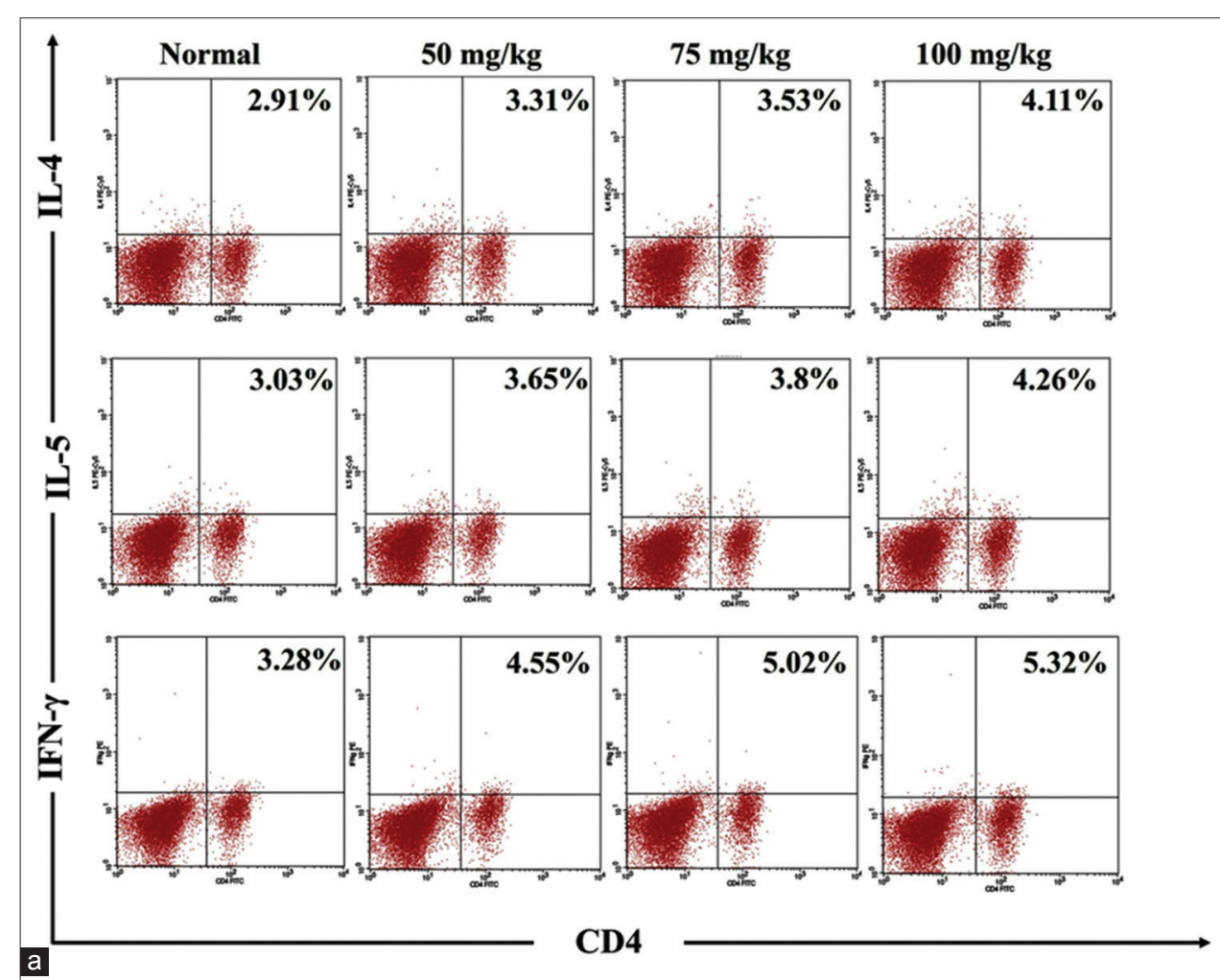

a

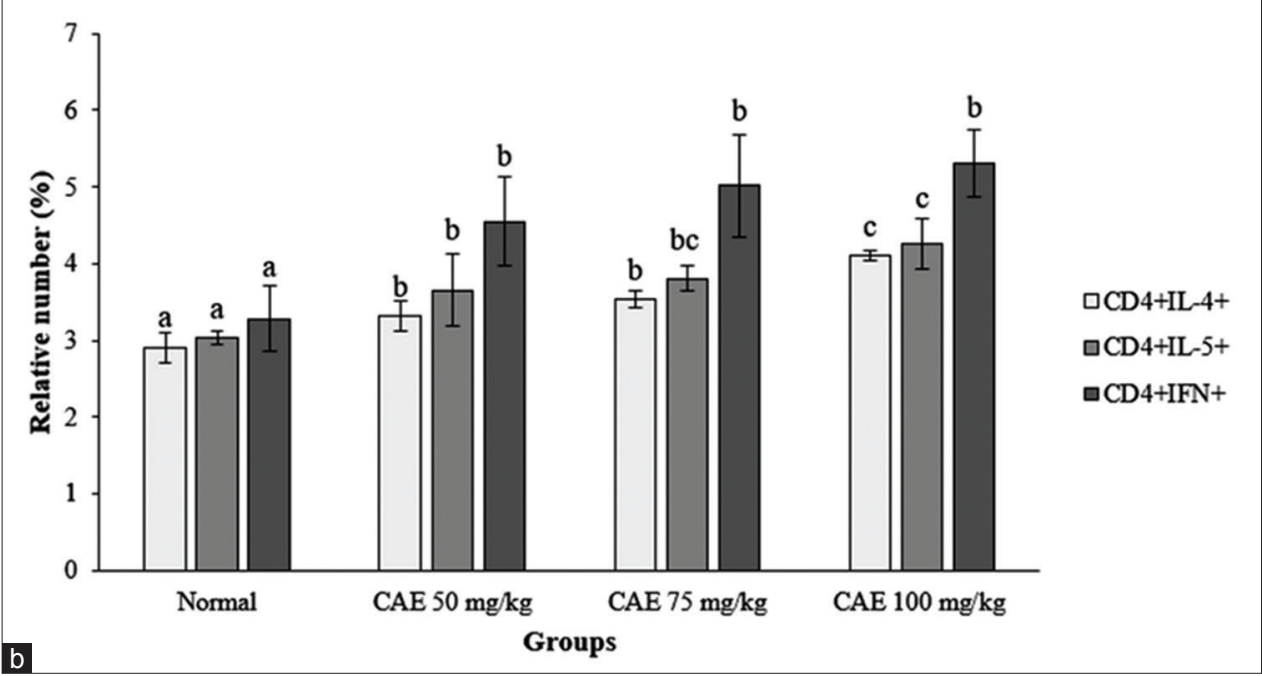

Figure-2: Flow cytometry analysis exhibited Thelper 1 and T helper 2 cells. (a) CD4 $4^{+}$interleukin- $4^{+}\left(\mathrm{IL}-4^{+}\right), \mathrm{CD}^{+} \mathrm{IL}-5^{+}$, and $\mathrm{CD} 4^{+}$interferon- $\mathrm{Y}^{+}\left(\mathrm{IFN}-\mathrm{\gamma}^{+}\right)$expressions on splenocytes and (b) $\mathrm{CD}^{+} \mathrm{IL}^{-} 4^{+}, \mathrm{CD}^{+} \mathrm{IL}-5^{+}$, and $\mathrm{CD} 4^{+}$IFN- $\mathrm{\gamma}^{+}$expressions were represented as mean \pm standard deviation ( $n=6$ for each group). The different letter on the chart was considered significantly different for each group $(p<0.05)$ and vice versa based on Duncan's multiple range test. CAE=Crude Anisakis extract.

\section{Discussion}

Marine food consumption, especially fish, is quite popular globally due to its nutritional content. Anisakis is one of the important biohazards in fishery products which may lead to a rejection by consumers and economic losses to the fish industry [17,21]. Nowadays, among nine Anisakis species, A. simplex (s.s) and Anisakis pegreffii are best known for causing infection in human. However, there is little information about A. typica causing infection. A. typica challenge in our research would greatly improve knowledge of anisakiasis besides A. simplex (s.s) and A. pegreffii epidemiology.
Our result suggests that the expression of CD $11 \mathrm{c}^{+}$(DCs) was increased after $A$. typica treatment. DCs have a responsibility to present antigen then elicited immune response during parasite infection. Macrophage, other antigen-presenting cells have reported to secrete IL-6 through toll-like receptors activation and elicit $\mathrm{Th}_{2}$ polarization after antigens, native carbohydrates derived from metacestode larvae parasites sensitization [22]. These results are in line with our study which suggests that A. typica challenge induces DCs maturation to secrete IL-6 as a pro-inflammatory cytokine. Another study reported that in vitro crude extract $A$. pegreffii elicits DCs to develop immune response by increase CCL3, CXCL4, 
CCL4, and granulocyte-macrophage colony-stimulating factor. DCs maturation in lymph node provokes pro-inflammatory IL-6 secretion and participates in $\mathrm{Th}_{2}$ differentiation [23].

Tregs are known to work synchronize with $\mathrm{Th}_{2}$ in the early phase of infection through TGF- $\beta$ signaling. Furthermore, Tregs elicit $\mathrm{Th}_{2}$ response counter worm infection [24] by attracting eosinophils, mast cells, basophils, and production of IgE [25]. Our study suggests that after 1 week challenged by A. typica, there is reduce of naive Tregs population. The previous study reported that $A$. simplex challenge represents the balanced between $\mathrm{Th}_{1} / \mathrm{Th}_{2}$ responses [13]. IL-4 secretion triggers IgE production by B-lymphocyte, while IL-5 involved in eosinophilic production under anisakiasis [26,27]. Elevated $\mathrm{Th}_{1}$-mediated response during anisakiasis was associated with $\mathrm{Th}_{17}$ activation [28] and severe GI symptoms, which displays the clinical manifestation in patients [29]. Furthermore, one of DCs subset $\left(\mathrm{CD} 11 \mathrm{c}^{\text {mid }} \mathrm{CD} 45 \mathrm{RB}^{\text {high }}\right)$ reported to activate $\mathrm{CD} 4^{+} \mathrm{T}$ cells to secrete the high levels of both IFN- $\gamma$ and IL-4 in nematode-infected mice [30].

\section{Conclusion}

We have evaluated the immune profile after A. typica challenged, which have generated new possibilities to understand the role of $A$. typica after infected mice. In our present study, A. typica infection exhibits a mixed $\mathrm{Th}_{1} / \mathrm{Th}_{2}$ pattern which more skewed to the pro-inflammatory state than the classical model of an allergic reaction to food antigens. Further studies are required to understanding the molecular mechanism of A. typica infection which may imply the human allergic reaction during parasite infection. Further experiments are needed to explain the detailed mechanism of Anisakis infection. More appropriate experiments such as different route of administration and sample preparation are expected to complete the detailed Anisakis infection mechanism.

\section{Authors' Contributions}

Concept: AA, ES, and AMH; Design: LH; Supervision: AA, ES, and AMH; Resources: LH; Materials: LH; Data collection and/or processing: LH; Analysis and/or interpretation: LH, AA, ES, and AMH; Literature search: LH; Writing manuscript: LH; Critical review: AA, ES, and AMH. All authors read and approved the final manuscript.

\section{Acknowledgments}

The authors acknowledge the Ministry of Marine Affairs and Fisheries Republic of Indonesia for research funding (grant no. 113/SJ/KP.532/III/2016), The authors also thankful to Fish Quarantine and Inspection Agency (FQIA) of Kupang, and INBIOIndonesia to assisting the research and for the helpful discussion.

\section{Competing Interests}

The authors declare that they have no competing interests.

\section{Publisher's Note}

Veterinary World remains neutral with regard to jurisdictional claims in published institutional affiliation.

\section{References}

1. Guardone, L., Nucera, D., Lodola, L.B., Tinacci, L., Acutis, P.L., Guidi, A. and Armani, A. (2018) Anisakis spp. larvae in different kinds of ready to eat products made of anchovies (Engraulis encrasicolus) sold in Italian supermarkets. Int. J. Food Microbiol., 268(2018): 10-18.

2. Yengkhom, O., Shalini, K.S., Subramani, P.A. and Michael, R.D. (2019) Stimulation of non-specific immunity, gene expression, and disease resistance in Nile tilapia, Oreochromis niloticus (Linnaeus, 1758), by the methanolic extract of the marine macroalga, Caulerpa scalpelliformis. Vet. World, 12(2): 271-276.

3. European Food Safety Authority. (2010) Scientific opinion on risk assessment of parasites in fishery products. EFSA J., 8(4): 1543

4. Mladineo, I. and Poljak, V. (2014) Ecology and genetic structure of zoonotic Anisakis spp. from Adriatic commercial fish species. Appl. Environ. Microbiol., 80(4): 1281-1290.

5. Ivanović, J., Baltić, M., Bošković, M., Kilibarda, N., Dokmanović, M., Marković, R., Janjić, J. and Baltić, B. (2017) Anisakis allergy in human. Trends Food Sci. Technol., 59(2017): 25-29.

6. Baptista-Fernandes, T., Rodrigues, M., Castro, I., Paixão, P., Pinto-Marques, P., Roque, L., Belo, S., Ferreira, P.M., Mansinho, K. and Toscano, C. (2017) Human gastric hyper infection by Anisakis simplex: A severe and unusual presentation and a brief review. Int. J. Infect. Dis., 64(11): 38-41.

7. Audicana, M.T., Italo, P.I. and Longo, A.N. (2017) Anisakis simplex, a new hero in the anaphylaxis scene. SM Emerg. Med. Crit. Care, 1(2): 1-6.

8. Morsy, K., Badr, A.M., Abdel-Ghaffar, F., El Deeb, S. and Ebead, S. (2017) pathogenic potential of fresh, frozen, and thermally treated Anisakis spp. Type II (L3) (Nematoda: Anisakidae) after oral inoculation into Wistar rats: A histopathological study. J. Nematol., 49(4): 427-436.

9. Diab, R.G., El Temsahy, M.M., Elkerdany, E.D. and Gaafar, M.R. (2011) A study of allergic sensitization to Anisakis species in experimental mice. Arch. Clin. Microbiol., 2(3): 1-7.

10. Cho, M.K., Park, M.K., Kang, S.A., Caballero, M.L., Perez-Pinar, T., Rodriguez-Perez, R., Ock, M.S., Cha, H.J., Hong, Y.C. and Yu, H.S. (2014) Allergenicity of two Anisakis simplex allergens evaluated in vivo using an experimental mouse model. Exp. Parasitol., 146(2014): 71-77.

11. George, J.F., Braun, A., Brusko, T.M., Joseph, R., Bolisetty, S., Wasserfall, C.H., Atkinson, M.A., Agarwal, A. and Kapturczak, M.H. (2008) Suppression by CD4+CD25+ regulatory T cells is dependent on expression of heme oxygenase- 1 in antigen-presenting cells. Am. J. Pathol., 173(1): 154-160.

12. Pleasance, J., Raadsma, H.W., Estuningsih, S.E., Widjajanti, S., Meeusen, E. and Piedrafita, D. (2011) Innate and adaptive resistance of Indonesian thin tail sheep to liver fluke: A comparative analysis of Fasciola gigantica and Fasciola hepatica infection. Vet. Parasitol., 178(3-4): 264-272.

13. Baeza, M.L., Conejero, L., Higaki, Y., Martín, E., Pérez, C., Infante, S., Rubio, M. and Zubeldia, J.M. (2005) Anisakis simplex allergy: A murine model of anaphylaxis induced by parasitic proteins display a mixed $\mathrm{Th}_{1} / \mathrm{Th}_{2}$ pattern. Clin. Exp. Immunol., 142(3): 433-440. 
14. Abo-Aziza, F.A.M., Hendawy, S.H.M., Namaky, A.H.E. and Ashry, H.M. (2017) $\mathrm{Th}_{1} / \mathrm{Th}_{2}$ balance and humoral immune response to potential antigens as early diagnostic method of equine Strongylus nematode infection. Vet. World, 10(6): 679-687.

15. Mattiucci, S., Paoletti, M., Colantoni, A., Carbone, A., Gaeta, R., Proietti, A., Frattaroli, S., Fazii, P., Bruschi, F. and Nascetti, G. (2017) Invasive anisakiasis by the parasite Anisakis pegreffii (Nematoda: Anisakidae): Diagnosis by real-time PCR hydrolysis probe system and immunoblotting assay. BMC Infect. Dis., 17(1): 1-9.

16. Mattiucci, S., Cipriani, P., Levsen, A., Paoletti, M. and Nascetti, G. (2018) Molecular epidemiology of Anisakis and anisakiasis: An ecological and evolutionary road map. Adv. Parasitol., 99(2018): 93-263.

17. Palm,H.W., Theisen, S., Damriyasa,I.M., Kusmintarsih,E.S., Oka, I.B.M., Setyowati E.A., Suratma, N.A., Wibowo, S. and Kleinertz, S. (2017) Anisakis (Nematoda: Ascaridoidea) from Indonesia. Dis. Aquat. Org., 123(2): 141-157.

18. Soewarlan, L.C., Suprayitno, E. and Nursyam, H. (2014) Identification of anisakid nematode infection on skipjack (Katsuwonus pelamis L.) from Savu Sea, East Nusa Tenggara, Indonesia. Int. J. Biosci., 5(9): 423-432.

19. Türck, P., Lacerda, D.S., Carraro, C.C., de Lima Seolin, B.G., Teixeira, R.B., Poletto Bonetto, J.H., Colombo, R., Schenkel, P.C., Belló-Klein, A. and da Rosa Araujo, A.S. (2018) Trapidil improves hemodynamic, echocardiographic and redox state parameters of right ventricle in monocrotaline-induced pulmonary arterial hypertension model. Biomed. Pharmacother., 103(7): 182-190.

20. Atho'illah, M.F., Safitri, Y.D., Nur'aini, F.D., Widyarti, S., Hideo, T. and Rifa'i, M. (2018) Soybean extract suppresses $\mathrm{B}$ cell activation through $\mathrm{TLR}_{3} / \mathrm{TLR}_{4}$ in high fat-high fructose diet mice. Turk. J. Immunol., 6(3): 95-103.

21. Bao, M., Pierce, G.J., Strachan, N.J.C., Pascual, S., González-Muñoz, M. and Levsen, A. (2019) Human health, legislative and socioeconomic issues caused by the fish-borne zoonotic parasite Anisakis: Challenges in risk assessment. Trends Food Sci. Technol., 86(4): 298-310.

22. Dissanayake, S., Amith, R.S. and Shahin, A. (2004) Taenia crassiceps carbohydrates stimulate IL-6 expression in naïve murine macrophages via toll-like receptors (TLRs). Mol. Immunol., 41(4): 391-398.

23. Napoletano, C., Mattiucci, S., Colantoni, A., Battisti, F., Zizzari, I.G., Rahimi, H., Nuti, M. and Rughetti, A. (2018) Anisakis pegreffii impacts differentiation and function of human dendritic cells. Parasite Immunol., 40(5): 1-12.

24. Cortés, A., Muñoz-Antoli, C., Esteban, J.G. and Toledo, R. (2017) $\mathrm{Th}_{2}$ and $\mathrm{Th}_{1}$ responses: Clear and hidden sides of immunity against intestinal helminths. Trends Parasitol., 33(9): 678-693.

25. Baird, F.J., Gasser, R.B., Jabbar, A. and Lopata, A.L. (2014) Foodborne anisakiasis and allergy. Mol. Cell. Probes, 28(4): 167-174.

26. Deo, S., Mistry, K., Kakade, A. and Niphadkar, P. (2010) Role played by $\mathrm{Th}_{2}$ type cytokines in IgE mediated allergy and asthma. Lung India, 27(2): 66.

27. Daschner, A., Cuéllar, C. and Rodero, M. (2012) The Anisakis allergy debate: Does an evolutionary approach help? Trends Parasitol., 28(1): 9-15.

28. Bušelić, I., Trumbić, Ž., Hrabar, J., Vrbatović, A., Bočina, I. and Mladineo, I. (2018) Molecular and cellular response to experimental Anisakis pegreffii (Nematoda, Anisakidae) thirdstage larval infection in rats. Front Immunol., 9(2018): 2055.

29. Gonzalez-Muñoz, M., Rodriguez-Mahillo, A.I. and Moneo, I. (2010) Different $\mathrm{Th}_{1} / \mathrm{Th}_{2}$ responses to Anisakis simplex are related to distinct clinical manifestations in sensitized patients. Parasite Immunol., 32(1): 67-73.

30. Li, Z., Liu, G., Chen, Y., Liu, Y., Liu, B. and Su, Z. (2011) The phenotype and function of naturally existing regulatory dendritic cells in nematode-infected mice. Int. J. Parasitol., 41(11): 1129-1137. 